\title{
Determination of Shoe Quality by Comparison of Two Methods for Improve Selection
}

\author{
$1^{\text {st }}$ Muhardi Saputra \\ Department Of Information System \\ Universitas Prima Indonesia \\ Medan, North Sumatera \\ $4^{\text {th }}$ Muhammad Syahputra Novelan \\ Department Of Computer System \\ Universitas Pembangunan Panca \\ Budi \\ Medan, North Sumatera
}

\author{
$2^{\text {nd }}$ Tubagus Prakoso \\ Department Of Information System \\ Universitas Prima Indonesia \\ Medan, North Sumatera \\ $5^{\text {th }}$ Abdul Meizar \\ Department Of Information System \\ Universitas Potensi Utama \\ Medan, North Sumatera
}

\author{
$3^{\text {rd }}$ jaswir singh \\ Department Of Information System \\ Universitas Prima Indonesia \\ Medan, North Sumatera \\ $6^{\text {th }}$ siti aisyah \\ Department Of Information System \\ Universitas Prima Indonesia \\ Medan, North Sumatera
}

\begin{abstract}
Using two methods in decision support according to some circles is very inefficient and redundant (excessive), because in terms of results will be the same. However, according to the author, it is not entirely true, sometimes comparing the two methods is necessary in increasing the confidence of the election (decision). Likewise, if we want to get something, we have to compare from several sources. So basically it will convince the choice (decision). The comparison of the two methods in this study is Simple Additive Weighted (SAW) and Weighting Product (WP) because it uses weight values as the basis of reference. The case told is choosing the quality of shoes based on the brand on the type of sport shoes (sports shoes). The purpose of this research is to determine the best shoe brand, but the main thing is to add value to the confidence of the choice because it has been tested by two methods.
\end{abstract}

Keywords:- Two Method, More Believe, Decision, Best Shoes.

\section{INTRODUCTION}

In the era of free trade like now, where competition for products / goods is increasingly rampant, the matter of product quality is very important to highlight. Because if this is not highlighted, the logical consequence is that the quality of the product offered can be displaced by the quality of other products that are more convincing to consumers. The general purpose of forming the quality of the product itself is to convince consumers that the best product according to consumer needs. Even to be more convincing, there are companies that dare to guarantee compensation if their products are not of high quality or are not in accordance with the promotions that are delivered.

The shop is a company that sells various shoe brands from standard quality to top quality. Along with the rapid development of competition and the arrival of sport shoe shops in Medan, the development of information technology and the size of the market to be handled, require companies to determine the best quality of sales of goods, making it easier for consumers to determine the best shoe brands.
Decision Support System as a computer-based system consisting of components including language system components, knowledge system components and problem processing system components that interact with one another. The use of one method can solve the problem of determining which shoes have quality. But the use of two methods in the comparison of determining the quality of shoes can be more convincing for consumers for the shoes they want to buy.

\section{REALATED WORK}

The method used by the writer in this research is Simple Additive Weighted (SAW) with Weighted Product (WP). The author determines because the two methods use the same reference, namely the weight of the assessment with different processing whether the results shown are the same in the search for shoe quality.

The SAW and WP methods have been widely used in the search for decision support. Among them is Harsiti (2017) in his research which revealed that he was solving problems including the difficulty in choosing a smartphone. This is due to the emergence of smartphones with attractive capabilities, relatively cheap prices, and other qualified facilities [1]. Elly Rahayu (2019) made a study aimed at implementing SAW media in determining the appropriate promotional media for LPP LPS Komputer Air Joman [2].

The SAW method is also often combined with other methods. usually combined with the Analytic Hierarchy Process (AHP) method. For example, Muhardi Saputra (2018) conducted a research that aims to make it easier for the head of the Muhamadiyah Medan branch in selecting a new department head by adjusting several predetermined criteria [3]. There is also other research which suggests that the incorporation of SAW AHP can increase the value of the decision to determine the best employee. By combining these two methods, the results increase the accuracy of the best employee recommendations [4].

Not only from the SAW point of view, the Weighted Product (WP) method has also been widely used in various studies. One of them is Nurul Fartindyyah's research (2014) 
using the WP method to determine the interests of high school students at SMA Negeri 13 Semarang based on the grades of SMP, UN SMP and student interests. The results achieved were almost $100 \%$ of students at SMA N 13 Semarang in accordance with their specialization [5]. Heru Supriyono (2015) raises the problem of how to determine good housing. The WP method can provide a solution. 11 criteria factors can be realized in determining the ideal occupancy for consumers [6].

The WP method is also often combined with other methods. Usually also compared with the AHP method. Several studies include the selection of high-performing cooperatives by comparing two methods, namely WP and AHP and the same results obtained in the first rank are Koperasi KPN Balaikota [7]. As well as research by Ananda Meidiyansyah (2016), it is stated that whether the pleasure of keeping a dog breed is based on an individual's sense of tau. It turns out that it is bigger based on the individual, that is, someone really likes the character of a dog, not based on race [8].

As for comparing the WP juxtaposed with the SAW method. One of them is Zaenal Alamsyah's research (2019) which uses the WP and SAW methods to analyze the determination of the admission of new teachers who will teach at SMA Negeri 1 Sudare [9]. Dan Berlilana (2018) uses the WP and SAW methods in determining the eligibility of a prosperous recipient [10]. All studies that compare the two methods have an objective that this comparison will increase confidence in the decision (selection).

\section{RESULT AND DISCUSSION}

This chapter contains a description of how the results of the calculation of the two methods, namely Simple Additive Weighting (SAW) and Weighting Product (WP) on the selection of quality shoes based on brands with the criteria of Canvas / Leather / Outer Material, Soles (inner tread), Seams, Stability, and Outside Tread.

This research makes data processing of problems in Win Sport Shoe Store. The store has many brands of shoes that are often asked by consumers which brands are of good quality in these brands. This makes it difficult for employees to explain which quality is to consumers.

In the process of determining the best shoe brand has some difficulties, so the process takes a long time. In the process of selecting the best shoes, especially boots, employees must first look at the data regarding the criteria for shoes that are sold, then they determine which is the best shoe brand that will be recommended later. Therefore it is necessary to determine the best shoe brand application to facilitate employees in recommending shoe products that will be offered to consumers based on the web.

\section{A. Research Framework}

This framework is the stages that will be carried out in order to solve the problem that will be discussed.

\section{$>$ Identify the Problem}

At this stage a review of the system will be examined to observe and explore deeper and explore the problems that exist in the current system. This stage is the first step to determine the formulation of the problem from research

\section{$>$ Analyze Problem}

The problems found will then be analyzed. The step in the problem analysis process is the step to understanding the problem that has been determined. By analyzing the problems that have been determined, it is expected that the problem can be understood properly.

\section{Seeting Goals}

Based on the understanding of the problems that have been analyzed, the next step is to determine the objectives to be achieved in this study. In this goal the target will be achieved, especially those that can overcome existing problems.

\section{$>$ Study Literature}

This research was conducted to complete the treasury of rules, concepts, theories that support in solving problems in this study. Research is also carried out through books, journals, which are related to research and other references. This study aims to collect data, both basic data and supporting data, where all the data is needed in research.

\section{Collecting Data}

Collecting data for training and testing of Simple Additive Weighted (SAW) and WP. The more data obtained, the better in solving the problem. Collect accurate data and divide the data into predetermined criteria. The division of criteria is used to facilitate the grouping of data.

\section{Analyze Simple Additive Weghted and Weighted Product Method}

After the data is collected, data analysis is performed to adjust the data activities to be processed in the Simple Additive Weighted and Weighted Product method which consists of several stages, namely defining the problem and determining the desired solution criteria, determining element priority, synthesis, measuring consistency, calculating normalization, calculating the ratio preferences, check consistency with the aim of meeting shoe quality

\section{$>$ Data Processing}

After the method analysis process at this stage the data processing consists of Canvas / Skin / Outer Material, Soles (Inner site), Stitching, Stability, and Outside Site. Based on these criteria, the SAW and WP data processing to produce a Decision Support System that determines the quality of shoe brands. 


\section{$>$ Implementation}

In accordance with data processing, at the implementation stage, testing of each of the quality criteria for cocoa beans that are worth selling is processed by Simple Additive Weighted manually to produce the feasibility of farmers who have quality cocoa beans worth selling, determining priority elements, synthesis, measuring consistency, calculating normalization, calculating preference ratios, checking consistency with the aim of fulfilling the quality requirements of shoes worthy of selling.

\section{Testing.}

At this stage, an assessment is made whether the software developed is in accordance with the expected objectives. The following are the testing mechanisms performed:

- Construct a test case that is a set of data or situations that will be used in testing.

- Determine the results to be expected by carrying out a manual calculation process.

- Running a test case

- Doing a comparison of test results and expected results, if there are differences in results, improvements will be made in accordance with the errors found.

\section{B. Simple Additive Weighted (SAW)}

In determining the selection of quality sports shoes based on the brand using the SAW method required criteria and weights to do the calculations so that it will be able to get the best alternative for the selection of quality sports shoes based on the brand.

In the SAW method there are criteria needed for the Selection of Quality of Sport Shoes by Brand. The weight value in the Criteria that have been determined by the decision maker Win Sport Shop can be seen in table 1. the following :

\begin{tabular}{|c|c|c|}
\hline Criteria & Information & Weighted Priority \\
\hline C1 & Material & $30 \%$ \\
\hline C2 & Inside Tread & $20 \%$ \\
\hline C3 & Stitches & $15 \%$ \\
\hline \multirow{2}{*}{ C4 } & Stability & $15 \%$ \\
\hline C5 & Outside Tread & $20 \%$ \\
\hline \multicolumn{2}{|c|}{ Total } & $100 \%$ \\
\hline
\end{tabular}

Table 1:- Table Criteria

From each of these criteria, weights will be determined, namely Bad (R), Fair (C) and Good (B)), and Very Good (SB).

\section{* Calculation:}

Simple Additive Weitghted calculation steps in the selection of quality drinking water, namely:

$>$ Alternative Determination. Determination of alternatives is the number of choices to be compared. In this case the shoe brand will be compared with the quality values of the sports shoes, as explained in table 2. the following:

\begin{tabular}{|c|c|c|}
\hline No & Alternative & Merk \\
\hline 1 & A1 & Merk Adidas \\
2 & A2 & Merk Nike \\
3 & A2 & Merk Reebox \\
\hline
\end{tabular}

Table 2:- Table Alternative

Determination of Criteria Value of All Alternatives

All alternatives will be assessed based on criteria, as explained in table 3 . the following:

\begin{tabular}{|c|c|c|c|c|c|}
\hline \multirow{2}{*}{ Alt } & \multicolumn{5}{|c|}{ Criteria } \\
\cline { 2 - 6 } & Material & $\begin{array}{c}\text { Inside } \\
\text { Tread }\end{array}$ & $\begin{array}{c}\text { Outside } \\
\text { Tread }\end{array}$ & Jahitan & Stability \\
\hline A1 & SB & B & SB & B & R \\
A2 & B & B & SB & B & B \\
A3 & SB & B & B & B & C \\
\hline
\end{tabular}

Table 3:- Assesment Criteria For Each Alternative

Determination of the Weight Value of all the criteria of each alternative

After evaluating the criteria for all alternatives, the next step is to transform the value of the criteria into weighting values.

\begin{tabular}{|c|c|c|c|c|c|}
\hline \multirow{2}{*}{ Alt } & \multicolumn{5}{|c|}{ Criteria } \\
\cline { 2 - 6 } & C1 & C2 & C5 & C3 & C4 \\
\hline A1 & 1 & 0.75 & 1 & 0.75 & 0.25 \\
A2 & 0.75 & 0.75 & 1 & 0.75 & 0.75 \\
A3 & 1 & 0.75 & 0.75 & 0.75 & 0.5 \\
\hline
\end{tabular}

Table 4:- Transformation of Criteria Assessment into Weight Assessment

Determination of the Maximum Value of each Criteria.

After transforming the value of the criteria into weight values, the next step is to determine the maximum value for each criterion. Can be seen in Table 5. the following:

\begin{tabular}{|c|c|c|c|c|c|}
\hline \multirow{2}{*}{ Alt } & \multicolumn{5}{|c|}{ CRITERIA } \\
\cline { 2 - 6 } & C1 & C2 & C5 & C3 & C4 \\
\hline A1 & 1 & 0.75 & 1 & 0.75 & 0.25 \\
A2 & 0.75 & 0.75 & 1 & 0.75 & 0.75 \\
A3 & 1 & 0.75 & 0.75 & 0.75 & 0.5 \\
\hline Maximum & 1 & 0.75 & 1 & 0.75 & 0.75 \\
\hline
\end{tabular}

Table 5:- Determination of Maximum Value

Normalization Calculation Method of Simple Additive Weighted

The method of calculating the Normalization of the SAW Method is the value of the criteria weight divided by the maximum value. After dividing the criteria weights from the maximum value, the Normalization value will be generated. 
Determination of the Vi value from the Simple Additive Weighted method

To get the value of $\mathrm{Vi}$ is to do a matrix multiplication between the results of normalization and the importance of weight.

$$
\begin{aligned}
& \mathrm{Vi}=\left[\begin{array}{lllll}
1,000 & 1,000 & 1,000 & 1,000 & 0,333 \\
0,750 & 1,000 & 1,000 & 1,000 & 1,000 \\
1,000 & 1,000 & 0,750 & 1,000 & 0,667
\end{array}\right] \mathrm{X} \\
& \left\{\begin{array}{l}
0,300 \\
0,200 \\
0,200 \\
0,150 \\
0,150
\end{array}\right\}
\end{aligned}
$$

Then the preference value for each alternetive.

$\mathrm{V} 1$ for $\mathrm{A} 1=(1,000 \times 0,300)+(1,000 \times 0,200)+$

$(1,000 \times 0,200)+(1,000 \times 0,150)+(0,333 \times 0,150)$.

$\mathrm{V} 2$ for $\mathrm{A} 2=(0.750 \times 0,300)+(1,000 \times 0,200)+$

$(1,000 \times 0,200)+(1,000 \times 0,150)+(1,000 \times 0,150)$.

$\mathrm{V} 3$ for $\mathrm{A} 3=(1,000 \times 0,300)+(1,000 \times 0,200)+$

$(0.750 \times 0,200)+(1,000 \times 0,150)+(0.667 \times 0.150)$.

Results

After calculating the value of $\mathrm{Vi}$, the following values can be obtained:

$\mathrm{V} 1=0.9$

$\mathrm{V} 2=0.925 \Rightarrow$ is the highest value (Nike Brand is Quality) $\mathrm{V} 3=0.9$

So that V2 which is A2 with initial Nike brand is based on good quality simple additive weighted method

\section{* Weighted Product (WP) Method}

The steps of calculating the Weighted Product (WP) method with Alternatives and Criteria are the same as the calculation method for Simple Additive Weighted (SAW).

\section{Determination Preferences}

Determination Preferences value in accordance with the decision maker and does not need to be fixed again because it is right, that is

$$
\begin{aligned}
& \mathrm{S} 1=>\mathrm{V} 1=\frac{4,714}{4,714+4,777+4,747}=\frac{4,714}{14,238}=0,331 \\
& \mathrm{~S} 2=>\mathrm{V} 2=\frac{4,777}{4,714+4,777+4,747}=\frac{4,777}{14,238}=0,336 \\
& \mathrm{~S} 3 \Rightarrow \mathrm{V} 3=\frac{4,747}{4,714+4,777+4,747}=\frac{4,747}{14,238}=0,333
\end{aligned}
$$

\section{Result}

After calculating the $\mathrm{Vi}$ value, the following values are obtained:

$\mathrm{V} 1=0.331$

$\mathrm{V} 2=0.336 \Rightarrow$ is the highest value (Nike Brand is Qualified)

$\mathrm{V} 3=0.333$

\section{CONCLUSION}

Based on the calculation of the simple additive weighted and weighted product methods, the Nike brand has the highest value even though it is only slightly different from the Reebox Brand. Even though it differs slightly, it is still the Nike brand that is determined to be the best brand. With a comparison of the two methods yielding the same conclusion, the confidence to choose the brand has been categorized as very confident $(100 \%)$.

\section{REFERENCES}

[1]. Harsiti, H., \& Aprianti, H. (2017). Sistem Pendukung Keputusan Pemilihan Smartphone dengan Menerapkan Metode Simple Additive Weighting (SAW). JSiI (Jurnal Sistem Informasi), 4.

[2]. Rahayu, E., Handayani, M., \& Rohminatin, R. (2019). IMPLEMENTASI METODE SAW DALAM MENENTUKAN MEDIA PROMOSI (STUDI KASUS PADA LPP LPS KOMPUTER AIR JOMAN). JURTEKSI, 5(2), 105-112.

[3]. Saputra, M., Sitompul, O. S., \& Sihombing, P. (2018, April). Comparison AHP and SAW to promotion of head major department SMK Muhammadiyah 04 Medan. In Journal of Physics: Conference Series (Vol. 1007, No. 1, p. 012034). IOP Publishing.

[4]. K. Elissa, "Title of paper if known," unpublished.

[5]. R. Nicole, "Title of paper with only first word capitalized," J. Name Stand. Abbrev., in press.

[6]. Y. Yorozu, M. Hirano, K. Oka, and Y. Tagawa, "Electron spectroscopy studies on magneto-optical media and plastic substrate interface," IEEE Transl. J. Magn. Japan, vol. 2, pp. 740-741, August 1987 [Digests 9th Annual Conf. Magnetics Japan, p. 301, 1982].

[7]. M. Young, The Technical Writer's Handbook. Mill Valley, CA: University Science, 1989. 